\title{
GAMBARAN TINGKAT DEPRESI PASIEN DIABETES MELLITUS DI KABUPATEN KENDAL
}

\author{
Livana PH${ }^{1}$, Indah Permata Sari ${ }^{1}$, Hermanto ${ }^{1}$ \\ ${ }^{1}$ Program Studi Ilmu Keperawatan, Sekolah Tinggi Ilmu Kesehatan Kendal \\ Email: livana.ph@gmail.com; \\ indahbriliantgirl@gmail.com;hermantokomting@yahoo.com
}

\begin{abstract}
ABSTRAK
Diabetes Mellitus merupakan penyakit yang bersifat menahun, berhubungan dengan suatu sistem dalam tubuh, disebabkan oleh berbagai faktor, yang ditandai dengan hiperglikemia dan hiperlipidemia, akibat kurangnya sekresi atau ketidak efektifan insulin yang telah disekresi oleh pankreas. Pasien Diabetes Mellitus harus melakukan terapi pengelolaan farmakologis dan non farmakologis untuk mencegah terjadinya komplikasi dan mengontrol kestabilan kadar gula darahnya. Terapi tersebut dapat menimbulkan dampak fisik maupun psikologis bagi pasien DM. Dampak psikologis yang dapat dirasakan oleh pasien Diabetes Mellitus adalah depresi. Penelitian ini bertujuan untuk mengetahui gambaran tingkat depresi pada pasien Diabetes Mellitus di wilayah dokter keluarga Djazariyah Kabupaten Kendal. Metode deskriptif kuantitatif. Besar sampel penelitian 37 responden. Alat ukur menggunakan kuesioner Depression Anxiety Stres Scale. Teknik sampling yang digunakan dalam penelitian ini yaitu purposive sampling. Cara analisis data dengan analisis univariat menggunakan distribusi frekuensi. Sebagian besar pasien Diabetes Mellitus normal atau tidak mengalami depresi. Peneliti memberikan saran bagi peneliti selanjutnya untuk menggunakan kuesioner Depression Anxiety Stres Scale yang telah dimodifikasi agar mempermudah responden dalam menjawab.
\end{abstract}

Kata kunci: Diabetes Mellitus, Depresi.

\begin{abstract}
Diabetes Mellitus is a chronic disease associated with a system in the body, caused by various factors, characterized by hyperglycemia and hyperlipidemia, due to a lack of secretion or ineffectiveness of insulin secreted by the pancreas. Diabetes Mellitus patients should perform pharmacological and nonpharmacologic management to prevent complications and control the stability of their blood sugar levels. Therapy can cause physical and psychological impact for DM patients. The psychological impact that can be felt by Diabetes Mellitus patients is depression. This study aims to determine describe the level of depression in Diabetes Mellitus patients in the Djazariyah family doctor area of Kendal Regency. quantitative descriptive method. The sample size was 37 respondents. The measuring instrument uses the Depression Anxiety Stress Scale questionnaire. The sampling technique used in this study was purposive sampling. How to analyze data with univariate analysis using frequency distribution. Most of Diabetes Mellitus patient is normal or not depressed. The researcher gave suggestions for further researchers to use the modified Depression Anxiety Stress Scale questionnaire to make it easier for respondents to answer.
\end{abstract}

Keywords: Diabetes Mellitus, Depression. 


\section{PENDAHULUAN}

Diabetes Mellitus (DM) merupakan penyakit yang bersifat menahun, berhubungan dengan suatu sistem dalam tubuh, dan disebabkan oleh berbagai faktor, yang ditandai dengan adanya jumlah kadar gula (glukosa) darah yang berlebihan (hiperglikemia) dan jumlah kadar lemak (lipid) yang berlebihan (hiperlipidemia), akibat kurangnya sekresi insulin, atau ketidak efektifan kerja insulin yang telah disekresi oleh pankreas (Baradero, Dayrit, \& Siswadi, 2009). Penyakit DM menjadi induk dari berbagai macam penyakit, sehinggapasien DM akan mengalami dampak berupa perubahan fisik maupun psikologis. Hal tersebut akan mempengaruhi motivasi pasien DM untuk menjaga kualitas hidupnya.

Prevalensi DM dari tahun ke tahun semakin meningkat. Data yang diperoleh dari World Health Organization (WHO), terdapat 422 juta pasien DM di dunia (Global report on diabetes mellitus, 2016). Prevalensi DM di Indonesia menurut hasil Riset Kesehatan Daerah (Riskesdas) terus mengalami kenaikan yaitu dari $1,1 \%$ pada tahun 2007 menjadi 2,1\% pada tahun 2013 (Riskesdas, 2013). Prevalensi DM di Jawa Tengah juga mengalami kenaikan setiap tahunnya, Dinas Kesehatan (Dinkes) Jawa Tengah melaporkan terdapat $13,6 \%$ pasien DM pada tahun 2013, pada tahun 2014 meningkat menjadi $14,96 \%$, dan pada tahun 2015 kembali meningkat menjadi 16,69\% (Dinkes Jateng, 2015). Prevalensi DM di Kabupaten Kendal mencapai 2.954 orang. Jumlah tersebut membuat DM menjadi kasus Penyakit Tidak Menular (PTM) kedua tertinggi setelah kasus hipertensi (Dinkes Kabupaten Kendal, 2012).
Pasien kasus PTM seperti DM harus melakukan terapi pengelolaan sehingga status kesehatannya dapat terkontrol dan terhindar dari komplikasi akibat penyakit tersebut (Tandra, 2008). Pengelolaan yang baik akan membantu pasien DM untuk hidup seperti orang normal pada umumnya dan memiliki umur yang panjang (Sutedjo, 2010). Perkumpulan Endokrinologi Indonesia (Perkeni) membagi dua macam terapi yang harus dilakukan oleh pasien DM selama hidupnya yaitu secara farmakologis berupa pemberian obat-obatan dan non farmakologis berupa pengaturan makanan, latihan jasmani, dan edukasi (Perkeni, 2011).

Terapi yang dilakukan oleh pasien DM tersebut akan menimbulkan suatu dampak tertentu, baik secara fisik maupun psikologis (Solichah, 2009). Dampak secara fisik yang dirasakan berupa perubahan berat badan, perubahan nafsu makan, sering mengalami nyeri, keletihan, dan gangguan tidur, sedangkan secara psikologis pasien DM akan mengalami stres, cemas, takut, sering merasa sedih, merasa tidak ada harapan, tidak berdaya, tidak berguna, dan putus asa (Tjokroprawiro, 2011). Permasalahan emosional yang sering dialami pasien DM antara lain penyangkalan (denial) terhadap penyakitnya sehingga mereka tidak patuh dalam menerapkan pola hidup yang sehat, mudah marah dan frustrasi karena banyaknya pantangan atau merasa telah menjalani berbagai jenis terapi tetapi tidak terjadi perubahan kadar gula darah yang signifikan, takut terhadap komplikasi dan resiko kematian, jenuh meminum obat yang harus dikonsumsi seumur hidup, atau bahkan mengalami depresi (Semiardji, 2009). Persoalan-persoalan psikologis tersebut akan berdampak terhadap 
kelangsungan atau kepatuhan proses pengelolaan DM. Penelitian yang dilakukan oleh Gonzales, Peyrot, McCarl, Collins, Serpa, Mimiaga, Safrien (2008) menunjukkan bahwa depresi berpengaruh secara signifikan pada perilaku ketidakpatuhan penderita DM dalam menjalankan proses terapi atau pengobatan.

Penyakit DM cenderung menimbulkan dampak yang bersifat negatif, tetapi penyakit ini juga dapat memberikan dampak yang positif seperti adanya kesejahteraan psikologispasien DM yang meningkat. Kesejahteraan psikologis merupakan suatu keadaan seseorang yang mampu menerima kekuatan dan kelemahan dirinya, membina hubungan positif dengan orang lain, mengarahkan perilakunya sendiri, mengembangkan potensi diri secara terus menerus, menguasai lingkungan, dan memiliki tujuan dalam kehidupannya (Rfyy \& Singer, 2006). Kesejahteraan psikologis yang baik pada pasien DM akan memberikan motivasi untuk meningkatkan kualitas hidupnya, sedangkan kesejahteraan psikologis yang buruk akan memberikan pengaruh atau dampak yang negatif bagi pasien DM untuk menjalani kehidupannya.

Upaya preventif atau pencegahan terjadinya DM dapat dilakukan oleh semua orang, sehingga dapat meminimalkan munculnya dampak-dampak yang dapat memperburuk kondisi kesehatan. Orang yang memiliki resiko DM, pasien DM tanpa komplikasi dan pasien DM dengan komplikasi harus melakukan pencegahan dengan cara pencegahan primer, sekunder maupun tersier. Pemantauan kadar glukosa darah merupakan salah satu upaya pencegahan terjadinya DM tersebut (Baradero, Dayrit, \& Siswadi, 2009). Pemantauan kadar glukosa darah rutin pada pasien DM menjadi bagian yang penting dari pengendalian penyakit (Kristiana, 2012).

Keberhasilan atau kepatuhan pasien DM untuk melakukan pemantauan glukosa darah harus melibatkan partisipasi atau peran dari keluarga pasien DM. Keluarga pasien DM berperan sebagai pemberi asuhan keperawatan secara informal yaitu dengan memberikan kesempatan kepada pasien DM untuk berlatih mengelola dirinya sendiri terutama untuk melakukan pemeriksaan kadar glukosa darahnya, dalam hal ini keluarga hanya memotivasi atau mengajak pasien DM untuk melakukan pemeriksaan kadar glukosa darahnya. Masalah akan muncul pada pasien DM yang tidak patuh dengan ajakan keluarganya untuk memeriksakan kadar glukosa darahnya, dan keluarga hanya memotivasi tetapi tidak mendampingi pemeriksaan yang harus dilakukan di laboratorium, rumah sakit, klinik, puskesmas, atau melakukan pemeriksaan kadar glukosa darah secara mandiri. Pasien DM yang belum menyadari pentingnya dan manfaat melakukan pemantauan kadar glukosa darah secara rutin juga menjadi penyebab pasien DM tidak patuh terhadap ajakan keluarganya untuk melakukan pemeriksaan tersebut (Sari, Susanti, dan Sumawati, 2014).

Hasil penelitian Tamara, Bayhakki, dan Nauli (2014) menunjukkan ada hubungan antara dukungan keluarga dan kualitas hidup pasien DM tipe 2 di RSUD Arifin Achmad Provinsi Riau. Dukungan keluarga yang diberikan dalam bentuk emosional, instrumental, penghargaan dan informasi dapat memberikan rasa nyaman dan dapat meningkatkan motivasi pasien DM dalam menjalani pengobatan dan perawatan diri. Hasil penelitian Priharianto, Maliya, dan 
Rosyid (2014) terdapat 21 pasien DM $(23,6 \%)$ mendapat dukungan yang kurang dari keluarga, 16 (18\%) diantaranya tidak teratur kontrol kadar gula darah dan 5 $(5,6 \%)$ lainnya teratur melakukan kontrol kadar gula darah, 46 pasien DM $(51,7 \%)$ mendapat dukungan yang cukup dari keluarga, $20 \quad(22,5 \%)$ diantaranya tidakteratur dan $26(29,2 \%)$ lainnya teratur melakukan kontrol kadar gula darah, 22 responden $(24,7 \%)$ mendapat dukungan yang baik dari keluarga, $7 \quad(7,9 \%)$ diantaranya tidak teratur dan 15 (16,9\%) lainnya teratur melakukan kontrol kadar gula darah.

Hasil studi pendahuluan yang peneliti lakukan pada pasien DM yang tergabung dalam Program Pengelolaan Penyakit Kronis (Prolanis) di wilayah kerja Dokter keluarga Djazariyah Kabupaten Kendal pada bulan September 2016 terdapat 54 pasien DM. Rata-rata pasien DM yang tergabung dalam Prolanis tersebut adalah perempuan. Hasil wawancara didapatkan bahwa 2 dari 3 pasien DM tidak melakukan kontrol kadar gula darah secara rutin karena terkendala biaya, dan tidak ada anggota keluarga yang mengantar. Mereka mengalami perubahan selera makan, sering merasa letih, sering merasa mengantuk, mengalami gangguan tidur, merasa sedih, merasa tidak berdaya, cemas, dan takut apabila penyakitnya dapat menimbulkan penyakit yang lain.

\section{METODE}

Penelitian ini merupakan penelitian kuantitatif yang bersifat deskriptif. Penelitian ini dilaksanakan di wilayah kerja Dokter keluarga Djazariyah Kabupaten Kendal. Pemilihan tempat penelitian ini berdasarkan adanya kelompok Prolanis pasien DM yang mengadakan kegiatan rutin setiap satu bulan sekali, sehingga memudahkan peneliti untuk bertemu dan melakukan penelitian dengan pasien DM tersebut. Populasi dalam penelitian ini yaitu pasien DM yang tercatat mengikuti kegiatan Prolanis terakhir pada bulan September 2016 di wilayah kerja Dokter keluarga Djazariyah Kabupaten Kendal, yang berjumlah 37 orang. Alat ukur menggunakan kuesioner Depression Anxiety Stres Scale. Teknik sampling yang digunakan dalam penelitian ini yaitu purposive sampling. Cara analisis data dengan analisis univariat menggunakan distribusi frekuensi.

\section{HASIL DAN PEMBAHASAN}

Karakteristik pasien DM dalam penelitian ini disajikan melalui tabel 1 dan gambaran tingkat depresi pasien DM disajikan melalui gambar 1 berikut.

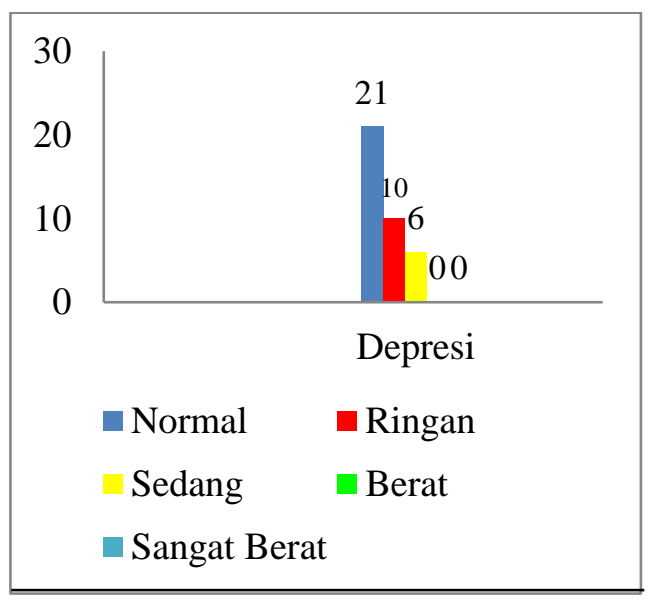

Gambar 1.

Distribusi frekuensi tingkat

Depresi pasien DM

\section{Tabel 1.}

Karakteristik pasien DM

\begin{tabular}{lcc}
\hline \multicolumn{1}{c}{ Karakteristik } & f & $\%$ \\
\hline Usia & & \\
\hline $25-60$ & 20 & 54 \\
\hline
\end{tabular}




\begin{tabular}{lcc}
\hline$>60$ & 17 & 46 \\
\hline Jenis Kelamin & & \\
\hline Perempuan & 20 & 54 \\
\hline Laki-laki & 17 & 46 \\
\hline Pendidikan & & \\
\hline Tidak sekolah & 3 & 8 \\
\hline SD & 6 & 16 \\
\hline SLTP & 10 & 27 \\
\hline SLTA & 13 & 35 \\
\hline PT & 5 & 14 \\
\hline Pekerjaan & & \\
\hline Bekerja & 22 & 59 \\
\hline Tidak bekerja & 15 & 41 \\
\hline Pendapatan & & \\
\hline$<$ UMR & 16 & 43 \\
\hline$>$ UMR & 13 & 35 \\
\hline UMR & 8 & 22 \\
\hline Status Perkawinan & & \\
\hline Menikah & 23 & 62 \\
\hline Belum menikah & 3 & 8 \\
\hline Dunda/Janda & 11 & 30 \\
\hline Lama menderita DM & \\
\hline$>5$ tahun & 23 & 62 \\
\hline$>6$ bulan & 13 & 35 \\
\hline tahun & & \\
\hline$<6$ bulan & 1 & 3 \\
\hline & & \\
\hline & & \\
\hline & & \\
\hline & & \\
\hline
\end{tabular}

\section{PEMBAHASAN}

\section{A. Karakteristik pasien DM}

1. Usia

Hasil penelitian menunjukkan bahwa mayoritas pasien DM berusia 25-60 tahun (54\%). Hasil penelitian ini sejalan dengan penelitian yang dilakukan oleh Sunjaya (2009), bahwa 47,5\% kelompok usia yang paling banyak menderita DM adalah kelompok usia 45-52 tahun. Proses penuaan pada kelompok usia tersebut menyebabkan berkurangnya kemampuan sel beta pankreas dalam memproduksi insulin, selain itu terdapat penurunan aktivitas mitokondria di selsel otot, hal ini berhubungan dengan kenaikan kadar lemak di otot sebesar

$30 \%$ dan memicu terjadinya resistensi insulin. Hasil penelitian yang dilakukan oleh Jelantik dan Haryati (2014), menunjukkan bahwa terdapat hubungan antara usia dengan kejadian DM tipe 2 yaitu sebagian besar responden memiliki umur lebih dari 40 tahun. Hasil penelitian Yusra (2010), mengatakan bahwa dengan bertambahnya usia pada seseorang, maka dapat menimbulkan suatu perubahan baik secara fisik, psikologis, maupun intelektual. Perubahan tersebut dapat menyebabkan kerentanan terhadap berbagai penyakit dan dapat menimbulkan kegagalan dalam mempertahankan homeostatis terhadap stres.

Peneliti menarik kesimpulan bahwa usia dapat meningkatkan resiko terjadinya DM. Seseorang dengan usia yang semakin bertambah, akan mengalami perubahan dan penurunan fungsi anatomis, fisiologis, dan biokimiawi, selain itu usia juga dapat mempengaruhi psikologis seseorang dalam menghadapi suatu perubahan kondisi atau masalah yang muncul dikehidupan sehari-hari.

2. Jenis Kelamin

Hasil penelitian menunjukkan bahwa mayoritas responden berjenis kelamin perempuan $(54 \%)$. Hasil penelitian ini sejalan dengan penelitian yang dilakukan oleh Zainuddin, Wasisto, dan Herlina (2015), dalam penelitiannya terdapat $53,3 \%$ pasien DM berjenis kelamin perempuan. Perempuan lebih beresiko terkena DM, karena secara fisik perempuan memiliki peluang kenaikan Indeks Massa Tubuh (IMT) yang lebih besar, selain itu sindroma siklus bulanan (premenstrual syndrome) dan pasca menopause membuat distribusi lemaklemak tubuh menjadi mudah 
terakumulasi. Pendapat Taylor (2008), mengatakan bahwa perubahan hormonal seperti penurunan estrogen dan progesteron akibat menopause dapat mempengaruhi kadar gula darah. Hasil penelitian Hasanuddin, Kristofel, Mahatrisni, Winasis dan Satrio (2011), menyatakan bahwa perempuan dengan DM dapat mengalami penurunan kualitas hidup seperti mengalami gangguan dalam beraktivitas, mengalami perubahan peran dan perubahan kondisi fisik, hal ini akan memicu timbulnya ansietas, stres, dan depresi. Penelitian tersebut tidak sejalan dengan penelitian yang dilakukan oleh Yusra (2010), dalam penelitiannya menunjukkan bahwa tidak ada hubungan antara jenis kelamin dengan kualitas hidup, laki-laki dan perempuan memiliki kemampuan yang sama dalam menyelesaikan masalah. Peneliti menarik kesimpulan bahwa perempuan lebih beresiko terkena DM karena perempuan memiliki beberapa faktor yang dapat mempengaruhi toleransi terhadap gula darah yang dapat meningkatkan resiko kejadian DM.

\section{Tingkat Pendidikan}

Hasil penelitian menunjukkan bahwa mayoritas responden berpendidikan SLTA (35\%). Hasil penelitian ini sejalan dengan penelitian yang dilakukan oleh Yusra (2010), bahwa terdapat hubungan antara tingkat pendidikan dengan kualitas hidup. Pendapat dari Notoatmodjo (2007), mengatakan bahwa tingkat pendidikan akan menentukan mudah atau tidaknya perubahan kemampuan dalam menjalankan perannya tersebut, hal ini dapat meningkatkan resiko terjadinya gangguan psikologis. seseorang dalam menerima dan memahami pengetahuan yang diberikan. Pendapat yang sama juga dikemukakan oleh Mihardja (2009), tingkat pendidikan dapat mempengaruhi kemampuan dan pengetahuan seseorang dalam menerapkan pola hidup sehat, salah satunya upaya untuk mencegah DM. Peneliti menarik kesimpulan bahwa tingkat pendidikan tidak mempengaruhi terhadap resiko terjadinya DM, tetapi pasien DM yang memiliki tingkat pendidikan yang tinggi akan lebih matang dalam proses perubahan dirinya sehingga akan lebih mudah menerima pengaruh dari luar yang bersifat positif, obyektif dan terbuka terhadap berbagai informasi terkait pemahaman tentang penyakit DM, perawatan diri, dan pelaksanakan manajemen perawatan DM termasuk pelaksanaan kontrol kadar gula darah.

4. Pekerjaan

Hasil penelitian menunjukkan bahwa mayoritas responden tidak bekerja (59\%). Aktivitas fisik yang dilakukan oleh orang yang tidak bekerja seperti pensiunan dan ibu rumah tangga kemungkinan besar lebih sedikit dibandingkan dengan orang yang memiliki aktivitas atau pekerjaan diluar rumah. Hasil penelitian ini sejalan dengan penelitian yang dilakukan oleh Trisnawati (2013), pekerjaan seseorang dapat mempengaruhi tingkat aktivitas fisik yang dilakukan. Aktivitas fisik mengakibatkan insulin semakin meningkat sehingga kadar gula darah akan berkurang. Jika insulin tidak mencukupi untuk mengubah glukosa menjadi energi maka akan timbul DM. Hasil penelitian tersebut sejalan dengan penelitian yang dilakukan oleh Ramadhanisa, Larasati dan Mayasari (2013), terdapat 96,3\% responden dalam penelitian tersebut memiliki aktivitas 
yang kurang dan memiliki kadar HbA1c yang buruk. Penelitian yang dilakukan oleh Hartono (2012), ditemukan sebagian besar pasien DM tipe II bekerja sebagai pegawai kantor. Pekerjaan mempengaruhi aktivitas fisik seseorang, selain itu mengkonsumsi makanan yang tinggi kalori dan tidak melakukan olahraga teratur, dapat meningkatkan resiko obesitas. Faktor pencetus yang lain dikemukakan oleh Suiraoka (2012), bahwa kemajuan teknologi dan kemapanan ekonomi membuat gaya hidup seseorang menjadi berubah, misalnya orang lebih cenderung pasif dalam bergerak seperti lebih memilih menggunakan kendaraan ketika keluar rumah daripada berjalan kaki. Pendapat tersebut mendukung penelitian yang dilakukan oleh Sunjaya (2009), diketahui bahwa orang yang memiliki aktivitas fisik yang ringan memiliki risiko 4,36 kali lebih besar untuk menderita DM dibandingkan dengan orang yang memiliki aktivitas yang sedang dan berat. Peneliti menarik kesimpulan bahwa aktivitas fisik yang ringan, yang dialami oleh orang yang tidak bekerja dapat meningkatkan resiko kejadian DM.

5. Tingkat Ekonomi

Mayoritas responden memiliki penghasilan dibawah UMR Kabupaten Kendal (43\%). Pendapat Fattah (2006), mengatakan bahwa kemampuan ekonomi masyarakat akan menentukan tingkat partisipasi dalam pembangunan misalnya partisipasi dalam menjaga kesehatan. Pendapat tersebut mendukung hasil penelitian yang dilakukan oleh Izzati, Wisnatul dan Nirmala (2015), mayoritas pasien DM berusia lebih dari 60 tahun (56,3\%), pada usia tersebut terjadi perubahan fisik sehingga responden tidak dapat beraktivitas seperti biasa dan berdampak pada masalah ekonomi.

Peneliti menarik kesimpulan bahwa tingkat ekonomi dari pasien DM dapat mempengaruhi kondisi DM yang dialaminya. Keterbatasan ekonomi dapat membatasi kemampuan dalam mencari informasi, perawatan dan pengobatan yang harus didapatkan oleh pasien DM tersebut, selain itu keterbatasan ekonomi juga dapat menimbulkan masalah psikologis yang dapat memperburuk kondisi kesehatannya.

6. Status Perkawinan

Mayoritas responden $(62,1 \%)$ memiliki status perkawinan menikah. Penelitian ini sejalan dengan penelitian yang dilakukan oleh Sari, Thobari dan Andayani (2011), seseorang yang terikat dalam status pernikahan memiliki kualitas hidup yang lebih baik dibandingkan seseorang yang tidak terikat dalam status pernikahan. Seseorang yang berstatus menikah akan mempunyai harga diriyang lebih tinggi dan mempunyai sumber koping yang adekuat dari pasangannya sehingga dapat lebih mengembangkan koping yang adaptif terhadap stressor yang muncul. Penelitian tersebut mendukung penelitian yang dilakukan oleh Putri, Yeni dan Handayani (2013), didapatkan data bahwa 76,2\% responden atau pasien DM yang memiliki peran keluarga yang baik, memiliki gula darah yang terkendali, sedangkan $23,8 \%$ pasien DM memiliki gula darah yang tidak terkendali. Penelitian yang dilakukan oleh Coffman (2008), pasien DM akan mendapatkan berbagai dukungan sosial yang dapat meningkatkan kepercayaan diri. Dukungan sosial yang utama adalah 
dukungan dari keluarga dan dukungan yang lain didapatkan dari teman dan petugas kesehatan. Peneliti menarik kesimpulan bahwa seseorang yang memiliki ikatan pernikahan akan memiliki dukungan yang lebih baik dari pasangannya, hal tersebut akan meningkatkan motivasi dari pasien DM untuk memiliki kualitas hidup yang baik dan terhindar dari gangguan psikologis.

7. Lama Menderita DM

Mayoritas responden $(62,0 \%)$ telah menderita DM selama lebih dari lima tahun, Pendapat Rahmat (2010), mengatakan bahwa pasien DM dapat mengalami penurunan kualitas hidup setelah menderita DM minimal selama satu tahun, hal ini disebabkan karena dalam rentang waktu tersebut pasien telah mengalami dan merasakan berbagai perubahan atau keluhan fisik dan psikis akibat penyakitnya tersebut. Pendapat tersebut tidak sejalan dengan penelitian yang dilakukan oleh Izzati dan Nirmala (2015), terdapat 87,5\% responden telah menderita DM selama lebih dari lima tahun. Lama waktu menderita DM tersebut menyebabkan munculnya berbagai pengalaman misalnya munculnya komplikasi DM, sehingga pasien DM tersebut termotivasi untuk patuh menjalankan diet DM, mengurangi stres, minum obat, sehingga tidak mengalami kenaikan kadar gula darah. Peneliti menarik kesimpulan bahwa lama waktu menderita DM dapat mempengaruhi perubahan dalam menerima dan menyikapi penyakit DM yang diderita.

\section{B. Gambaran tingkat depresi pasien DM}

Terdapat 21 responden $(57,0 \%)$ normal atau tidak mengalami depresi, 10 responden $(27,0 \%)$ mengalami depresi ringan, dan 6 responden $(16,0 \%)$ mengalami depresi sedang.

Hal tersebut dapat diketahui dari pertanyaan kuesioner DASS yang telah digunakan dalam penelitian ini, yaitu sebanyak $100 \%$ pasien DM merasa bahwa hidupnya berarti. Sebagian besar yaitu sebanyak $86,4 \%$ pasien DM tidak dapat merasakan kenikmatan dari berbagai hal yang dilakukan. Hal ini terjadi pada pasien DM karena mereka merasa bahwa usia yang semakin tua, tidak bekerja, dan penghasilan yang rendah akan mempengaruhi kehidupannya. Pasien DM akan mengalami penurunan produktifitas sehingga sesuatu yang mereka kerjakan tidak akan mencapai target tertinggi seperti yang diharapkan.

Peneliti menarik kesimpulan bahwa pasien DM yang memiliki depresi tetap memiliki kepercayaan diri dan harga diri yang baik. Pasien DM harus selalu berpikir positif terhadap diri sendiri, orang lain, maupun situasi dan lingkungan sekitar karena berpikir positif akan mempengaruhi emosi dan tingkah laku, hal ini akan memberikan hasil kesehatan seperti yang diharapkan atau menjadi lebih baik.

\section{SIMPULAN DAN SARAN \\ Simpulan}

Berdasarkan hasil penelitian dapat disimpulkan bahwa mayoritas pasien DM berusia 25-60 tahun, berjenis kelamin perempuan, pendidikan terakhir SLTA, tidak bekerja, memiliki penghasilan kurang dari UMR Kabupaten Kendal, menikah, dan lama menderita DM lebih dari lima tahun, dan tidak mengalami depresi atau normal.

\section{Saran}

Peneliti memberikan saran kepada pasien DM untuk dapat meningkatkan pengetahuan terkait dengan gambaran dampak psikologis seperti depresi yang 
dapat muncul pada pasien DM, sehingga pasien DM mampu mendeteksi secara dini tanda-tanda dampak psikologis yang terganggu, dan dapat segera mengatasi gangguan tersebut dengan meminta bantuan ke tempat pelayanan kesehatan untuk diberikan terapi atau pengobatan.

\section{DAFTAR PUSTAKA}

Baradero, M., Dayrid, M.W \& Siswadi, Y. (2009). Pasien gangguan endokrin. Jakarta: EGC.

Coffman, M.J. (2008). Effects of tangible social support and depression on diabetes self-efficacy. Journal of Gerontological Nursing.

Fattah, Nanang. (2006). Ekonomi dan pembiayaan pendidikan. Bandung: Remaja Posdakarya.

Global report on diabetes mellitus. (2016). WHO Library Cataloguing-inPulication Data. World Health Organization.

Gonzales, J.S., Peyrot, M., McCarl, L.A., Collins, E.M., Serpa, L., Mimiaga, M.J., Safrien, S.A. (2008). Depression and diabetes treatment nonadherence: a meta-analysis. http://care.diabetesjournals.org (Diakses pada tanggal 19 Desember 2016).

Hartono, R (2012), Hubungan asupan serat larut (soluble dietary fiber) dan aktivitas fisik dengan kejadian diabetes melitus tipe II pasien rawat jalan di RSUD Dr. Rubini Mempawah Kalimantan Barat.http://old.fk.ub.ac.id.

(Diakses pada tanggal 4 Februari 2017).

Hasanuddin, Kristofel, Mahatrisni, Winasis \& Satrio (2011). Anxieties/desires:
90 insights for marketing to youth, women, netizen. Jakarta: PT Gramedia Pustaka Utama.

Izzati, Wisnatul \& Nirmala. (2015). Hubungan tingkat stres dengan peningkatan kadar gula darah pada pasien diabetes mellitus di wilayah kerja Puskesmas Perkotaan Rasimah Ahmad Bukittinggi. STIKes Yarsi Sumatera Barat Bukittinggi.

http://ejournal.stikesyarsi.ac.id. (Diakses pada tanggal 25 November 2016).

Kristiana, F. (2012). Awas pankreas rusak penyebab diabetes. Jakarta: Cerdas Sehat.

Perkeni. (2011). Konsensus pengelolaan dan pencegahan diabetes mellitus 2 di Indonesia. Jakarta.

Ramadhanisa, Aqsha, Larasati dan Mayasari (2013). Hubungan aktivitas fisik dengan kadar HbAlc pasien diabetes melitus tipe II di Laboratorium Patologi Klinik RSUD Dr. H Abdul Moeloek Bandar Lampung.

Http//httpjuke.kedokteran.unila.ac.i

d. (Diakses pada tanggal 5 Februari 2017).

Rfyy, C.D. \& Singer, B.H. (2006). Best news yet on the six-factor model of well being. Social Science Research.

Riset Kesehatan Dasar Riskesdas 2013. http://www.depkes.go.id. (Diakses pada tanggal 24 September 2016).

Sari, Susanti \& Sukmawati. (2014). Peran keluarga dalam merawat pasien diabetik di rumah. Jurnal Ners LENTERA. 
Sari, R. M., Thobari, J.A., \& Andayani, M. T. (2011). Evaluasi kualitas hidup pasien DM tipe 2 yang diterapi rawat jalan dengan anti diabetik oral di RSUP dr. sardjito. Jurnal Manajemen dan Pelayanan Farmasi. http://jmpf.farmasi.ugm.ac.id.

(Diakses pada tanggal 7 Januari 2017).

Semiardji, G. (2009). Stres emosional pada penyandang diabetes. Penatalaksanaan diabetes melitus terpadu edisi kedua. Jakarta: Balai Penerbit FKUI.

Sunjaya, I. N. (2009). Pola konsumsi makanan tradisional Bali sebagai faktor risiko diabetes melitus tipe 2 di Tabanan. Jurnal Skala Husada.

Suiraoka I, P, (2012). Penyakit degeneratif, mengenal, mencegah, mengurangi risiko 9 penyakit degeneratif. Yogyakarta: Nuha Medika.

Sutedjo. (2010). 5 strategi penderita diabetes mellitus berusia panjang. Yogyakarta: Kanisius.

Tamara, Bayhakki \& Nauli (2014). Hubungan antara dukungan keluarga dan kualitas hidup pasien diabetes mellitus tipe II di RSUD Arifin Achmad Provinsi Riau.
Tandra, Hans. (2008). Segala sesuatu yang harus anda ketahui tentang diabetes: Panduan lengkap mengenal dan mengatasi diabetes dengan cepat dan mudah. Jakarta: PT Gramedia Pustaka Utama.

Taylor, C (2008). Gula darah dan menopause kenali tanda awal ketidakseimbangan menopause. http://ezinearticles.com. (Diakses pada tanggal 7 Januari 2017).

Trisnawati, S., Setyorogo, S., (2013). Faktor risiko kejadian diabetes melitus tipe II di Puskesmas Kecamatan Cengkareng Jakarta Barat Tahun 2012. Jurnal Ilmiah Kesehatan.

Yusra, Aini. (2010). Hubungan antara dukungan keluarga dan kualitas hidup pasien DM tipe 2 di Poliklinik Penyakit Dalam Rumah Sakit Umum Pusat Fatmawati Jakarta. Tesis. www.lontar.ui.ac.id. (Diakses pada tanggal 7 Januari 2017).

Zainuddin, Wasisto \& Herlina. (2015). Hubungan stres dengan kualitas hidup penderita diabetes mellitus tipe 2. http://download.portalgaruda.org. (Diakses pada tanggal 7 Januari 2017). 